\title{
With out a quality management tool, all HIV Managers shall not realise any steps forward for improvement: a Taso Uganda experience
}

\author{
Denis Mpiima*, Ceasar Luzze, Nicholas Kizito \\ From $16^{\text {th }}$ International Symposium on HIV and Emerging Infectious Diseases \\ Marseille, France. 24-26 March 2010
}

\section{Background}

To provide direction of what needs to be done and how they will be accomplished. To set a framework for holding the HIV programme and service providers accountable for the quality of patient care.

It's a basis for self-evaluation for next cycle of improvement.

\section{Methods}

Start with your baseline assessment from where a quality statement is chosen.

The materials include Quality statement, quality program, performance measurement system, determining quality improvement goals, stakeholders \& patient participation, an implementation plan and evaluation.

Determine an active case load where a sample is got through a computer automated system or manual lists.

Using performance indicators, patient's files sampled are reviewed by the quality team.

Results are shared and discussed with the quality team, staff and then another quality statement can be made.

Though many performance gaps can be identified the rule of one is employed in selecting the quality statement.

\section{Results}

The quality statements focused on "Improving CD4 monitoring" TB assessment and continuity in care and below are the results from the follow up.

Baseline $30 \%$ in sample of 100 (active Caseload = 5392) and from the follow up CD4 improved to $33 \%$ in a sample of 107 (active Caseload $=5,660$ ).

* Correspondence: mpiima_d@yahoo.com

The AIDS Suport Organisation, Kampala, Uganda
Continuity baseline $90 \%$ follow up $=98 \%$.

TB assessment (baseline 92\% follow up $=99 \%$.

\section{Discussion}

There was improvement in all the areas of focus due to interventions with 3\% in CD4 monitoring, $8 \%$ improvement continuity in care and $6 \%$ improvement in $\mathrm{TB}$ assessment. Any improvement has to be appreciated by the team. For continued and sustained quality HIV programme service delivery, its very essential period monitoring and evaluations through small scale internal surveys. All HIV service delivery units should have a quality management tool.

Published: 11 May 2010

doi:10.1186/1742-4690-7-S1-P61

Cite this article as: Mpiima et al:: With out a quality management tool, all HIV Managers shall not realise any steps forward for improvement: a Taso Uganda experience. Retrovirology 2010 7(Suppl 1):P61.

Submit your next manuscript to BioMed Central and take full advantage of:

- Convenient online submission

- Thorough peer review

- No space constraints or color figure charges

- Immediate publication on acceptance

- Inclusion in PubMed, CAS, Scopus and Google Scholar

- Research which is freely available for redistribution

Submit your manuscript at www.biomedcentral.com/submit
Biomed Central 